\title{
Chemical Composition of Flours Made of Residues from the King Palm (Archontophoenix alexandrae) Industry
}

\author{
Manoela Alano Vieira, Rossana Podestá, Karina Cardoso Tramonte, Renata Dias de Mello \\ Castanho Amboni, Karina Nunes de Simas, Sandra Regina Paulon Avancini and Edna \\ Regina Amante* \\ Departamento de Ciência e Tecnologia de Alimentos; Centro de Ciências Agrárias; Universidade Federal de Santa \\ Catarina; Rod. Admar Gonzaga, 1346; 88034-00; Florianópolis - SC - Brasil
}

\begin{abstract}
Residues from King palm (Archontophoenix alexandrae) processing were used for the production of flours, which were then chemically characterized. The protein content in these flours ranged from 3.62 to $9.75 \mathrm{~g} / 100 \mathrm{~g}$ and was higher in sifted leaf flour (SLF). The dietary fiber contents varied from 64 to $72 \mathrm{~g} / 100 \mathrm{~g}$. These values were high when compared to those of flours used in human nutrition. Analysis of anti-nutritional factors showed phytate contents to be below the levels that affected the bioavailability of minerals in human diet. Tannin contents were compatible with those found in legumes, between 0 and $2000 \mathrm{mg} / 100 \mathrm{~g}$. These flours showed high mineral content, which suggested a possibility for them to be used as food supplement. However, the bioavailability of these minerals could be affected by high total dietary fibre concentrations and anti-nutritional components contained in the samples.
\end{abstract}

Key words: Archontophoenix alexandrae, residues, flour, chemical analysis

\section{INTRODUCTION}

Archontophoenix alexandrae, commonly known as king palm, is endemic to the tropical forests of eastern Australia. King palm has been shown as an alternative species in heart-of-palm production, due to the exhaustion of natural reserves of Euterpe edulis Mart. in the Atlantic forest, or due to the continuous extraction of Euterpe oleraceae Mart. from the Amazon forest (Ramos and Heck, 2003; Bovi and Spiering, 2004). A. alexandrae produces heart-of-palm (locally known as palmito) of the noblest type, with higher quality and superior flavour when compared to that of Euterpe oleracea Mart. (açaí palm), which currently supplies more than $80 \%$ of the palmito traded in the international market (Bovi, 1998).

Residues from palmito processing, according to Ribeiro (1996), comprise 80-90\% of total palm weight, with some variations depending on the species. In spite of increasing interest in the utilization of industrial residues as well as in residue valorisation studies (Silva et al., 2001; Oliveira et al., 2002), only two research studies on the utilization of king palm residues were published" (Vieira et al., 2008; Simas et al., 2009). The chemical composition of several plants has been studied for human or animal nutrition, chemical and pharmaceutical use, and also as an alternative for economic valuation of natural

\footnotetext{
* Author for correspondence: eamante@cca.ufsc.br
} 
resources and preservation. However, since the 1990's, several research groups have shown a growing interest regarding the composition of vegetable species, as can be seen by the significant increase in studies reported in literature in recent years (Amante et al., 1999; Almeida et al., 2002; Kawashima and Soares, 2003; Grupta et al., 2004; Paduá et al., 2004; Matias et al., 2005; Porres et al., 2005).

The chemical composition of king palm residues is fundamental to know their potential as a new raw material. Despite the nutritional, environmental, and economical importance of A. alexandrae, there is no information available on its complete chemical analysis or on the presence of antinutritional factors and mineral contents.

The aim of this study was to evaluate the chemical properties of the flours prepared with residues from king palm (A. alexandrae) processing, enlarging the perspectives which determine their use, and to prospect new market segments for their potential uses - consequently reducing the residual load on the environment.

\section{MATERIALS AND METHODS}

\section{Production of flour}

In this work, fifteen organic A. alexandrae plants were used. After removing the heart-of-palm (palmito), the residues from organic king palm processing (leaf sheaths and leaves) were washed and oven-dried $\left(60^{\circ} \mathrm{C}, 48 \mathrm{~h}\right)$ in a forced air oven (Model 171, FABBE, São Paulo, Brazil). The dried raw material was milled in a hammer mill (Brameitar) to a dry 42 sieve size powder, producing leaf sheath flour (LSF) and leaf flour (LF). Part of these two flours was screened to pass through a 60 mesh sieve (British Standard Screen) to remove the most fibrous parts, producing sifted leaf flour (SLF) and sifted leaf sheath flour (SLSF).

Samples of LF, LSF, SLF and SLSF were packaged in an airtight plastic bag and stored in a freezer $\left(-18 \pm 2{ }^{\circ} \mathrm{C}\right)$ until required.

\section{Flour yield and chemical analysis}

The yield of flour made of king palm residues was determined gravimetrically through the relation between in natura residue weight and dry flour weight, expressed in percentages. Moisture, total ash, and lipid contents were analysed according to the methods of the Association of Official Analytical Chemists (1998); total nitrogen was determined by Kjeldahl method and crude protein by using the 6.25 conversion factor (AOAC, 1998). The soluble and insoluble dietary fibre content was analysed according to the methods of the American Association of Cereal Chemists (1999). The total carbohydrate was calculated by difference as $100(\%$ moisture $+\%$ ash $+\%$ lipid + $\%$ protein $+\%$ total dietary fibre). Energy values (Kcal) were calculated by applying the conversion factors of ATWATER which considered $4 \mathrm{Kcal} / \mathrm{g}$ for protein and carbohydrates, and $9 \mathrm{Kcal} / \mathrm{g}$ for lipid (Watt and Merrill, 1999). All the analyses were performed in triplicate.

\section{Anti-nutritional factors}

Phytic acid was determined according to the method of Thompson and Erdman (1982) by the measurement of residual iron remaining in solution after the precipitation of the Fe-IP6 complex, and tannin content was determined according to the method described by Price et al. (1978).

\section{Mineral determination}

Samples were reduced to ash at $580-600^{\circ} \mathrm{C}$ for approximately $12 \mathrm{~h}$. The ash was solubilised in nitric acid (1N), heated on a plate for 2-3 minutes and transferred to volumetric balloons, with the final volume of $100 \mathrm{~mL}$ supplemented with nitric acid (AOAC, 1990). Calcium, magnesium, iron, zinc, and manganese contents were determined through atomic absorption spectrophotometry by using a Perkin-Elmer Analyst 300 spectrophotometer. Lanthanum was added to calcium and magnesium samples to prevent interferences caused by phosphate ions. Potassium and sodium were determined through atomic emission spectrophotometry by using a PerkinElmer Analyst 300 spectrophotometer (AOAC, 1990).

Phosphorus was determined through the AOAC (1990) method by using a UV- VIS spectrophotometer (Hitachi Model U-1800). Readings of these elements were made at the following wavelengths $\left(\lambda_{\mathrm{s}}\right)$ in $\mathrm{nm}: \lambda_{\mathrm{Mg}}=258.3 ; \lambda_{\mathrm{Zn}}=$ 213.9; $\lambda_{\mathrm{Mn}}=57.6 ; \lambda_{\mathrm{Ca}}=422.7 ; \lambda_{\mathrm{Fe}}=261.2$ and $\lambda_{\mathrm{P}}=$ 420.0 . 


\section{Statistical analysis}

Mean \pm SD values were calculated and the data were subjected to analysis of variance. If a significant $F$-test was noted, averages were separated by using Tukey multiple range test. Significance was accepted at $P \leq 0.05$.

\section{RESULTS AND DISCUSSION}

\section{Yield and chemical analysis}

Due to partial removal of the most fibrous parts from these flours during the sifting process, the yields of the sifted flours showed lower values when compared to those of the non-sifted flours (Table 1).

The values obtained for the composition of the sifted and the non-sifted flours of King palm residues can be found in Table 2 .

Flour moistures were in accordance with the current legislation standard, which established a maximum of $10.0 \mathrm{~g} / 100 \mathrm{~g}$ (CNNPA, 1978).

High values of dietary fibres, proteins and total ash in flours of king palm residues were observed. The values for proteins, total lipids, and ash found in the sifted flours were higher than those of the nonsifted flours, while the values for soluble and insoluble fibres were lower. Therefore, the sifted flours showed a higher energetic and nutritional value when compared to the non-sifted flours. The sieving of king palm flours showed the development of flours with different properties and applications due to the differences in its composition.

Table 1 - Yield in g/100g of leaf flour (LF), sifted leaf flour (SLF), leaf sheath flour (LSF) and sifted leaf sheath flour (SLSF) made of king palm (Archontophoenix alexandrae) residues.

\section{Flours}

Mean \pm standard deviation $\left(\mathrm{g} / 100 \mathrm{~g}^{-1}\right)(\mathrm{n}=3)$

$\begin{array}{cc}\text { LF } & 40.3 \pm 1.13^{\mathrm{a}} \\ \text { SLF } & 37.3 \pm 1.15^{\mathrm{b}} \\ \text { LSF } & 17.7 \pm 1.15^{\mathrm{c}} \\ \text { SLSF } & 10.7 \pm 1.12^{\mathrm{d}}\end{array}$

Average values in the same row followed by different superscript letters are significantly different (P $\leq 0.05)$.

Results are mean \pm standard deviation of three determinations.

Table 2 - Chemical composition and energetic value of leaf flour (LF), sifted leaf flour (SLF), leaf sheath flour (LSF) and sifted leaf sheath flour (SLSF) of king palm (Archontophoenix alexandrae) residues.

\begin{tabular}{|c|c|c|c|c|}
\hline \multirow{2}{*}{ Composition } & \multicolumn{4}{|c|}{ Mean \pm standard deviation } \\
\hline & $\mathbf{L F}$ & SLF & LSF & SLSF \\
\hline$\left(\mathrm{g} 100 \mathrm{~g}^{-1}\right)$ & \multicolumn{4}{|c|}{$(n=3)$} \\
\hline Moisture & $8.51 \pm 0.08^{\mathrm{a}}$ & $8.41 \pm 0.03^{\mathrm{a}}$ & $8.81 \pm 0.02^{b}$ & $7.63 \pm 0.09^{c}$ \\
\hline Total ash & $5.75 \pm 0.04^{\mathrm{a}}$ & $6.35 \pm 0.06^{\mathrm{b}}$ & $4.28 \pm 0.05^{\mathrm{c}}$ & $4.54 \pm 0.08^{\mathrm{d}}$ \\
\hline Total lipids & $2.15 \pm 0.02^{\mathrm{a}}$ & $2.71 \pm 0.06^{b}$ & $0.981 \pm 0.08^{\mathrm{c}}$ & $1.14 \pm 0.09^{\mathrm{d}}$ \\
\hline Crude Protein (N x 6,25) & $9.24 \pm 0.03^{\mathrm{a}}$ & $9.75 \pm 0.05^{b}$ & $3.62 \pm 0.09^{c}$ & $3.82 \pm 0.08^{\mathrm{d}}$ \\
\hline Total dietary fibre & $68.2 \pm 0.02^{\mathrm{a}}$ & $64.9 \pm 0.06^{b}$ & $72.9 \pm 0.03^{c}$ & $65.9 \pm 0.05^{\mathrm{d}}$ \\
\hline Soluble fibre & $2.76 \pm 0.03^{\mathrm{a}}$ & $2.71 \pm 0.03^{\mathrm{a}}$ & $3.65 \pm 0.02^{\mathrm{b}}$ & $2.07 \pm 0.07^{\mathrm{c}}$ \\
\hline Insoluble fibre & $65.2 \pm 0.02^{\mathrm{a}}$ & $62.2 \pm 0.09^{b}$ & $69.2 \pm 0.03^{\mathrm{c}}$ & $63.9 \pm 0.04^{\mathrm{d}}$ \\
\hline Total carbohydrates ${ }^{*}$ & $6.15 \pm 0.04 a$ & $7.88 \pm 0.05 b$ & $9.41 \pm 0.05 c$ & $16.97 \pm 0.07 \mathrm{~d}$ \\
\hline $\mathrm{Kcal} / 100 \mathrm{~g}$ & $80.91 \pm 0.04^{\mathrm{a}}$ & $94.91 \pm 0.05^{\mathrm{b}}$ & $60.94 \pm 0.07^{\mathrm{c}}$ & $93.42 \pm 0.08^{b}$ \\
\hline
\end{tabular}

Average values in the same row followed by different superscript letters are significantly different $(\mathrm{P} \leq 0.05)$.

Results are mean \pm standard deviation of three determinations.

*Calculated by difference. 
The king palm flours showed higher contents of dietary fibre than those reported for cereals and brans (Chaudhary and Weber, 1990; FilizetteCozzi and Lajolo, 1991; Sudha et al., 2007).

LF, SLF, LSF, SLSF showed higher amounts of soluble dietary fibre than those reported for cereals such as hard wheat $(1.61 \mathrm{~g} / 100 \mathrm{~g})$, corn $(1.45$ $\mathrm{g} / 100 \mathrm{~g})$, sorghum $(1.42 \mathrm{~g} / 100 \mathrm{~g})$, and similar amounts to those reported for barley $(2.56 \mathrm{~g} / 100 \mathrm{~g})$ (Ragaee et al., 2006). The king palm flours were significantly higher in insoluble dietary fibre contents when compared with barley (22.07 $\mathrm{g} / 100 \mathrm{~g})$, corn $(13.50 \mathrm{~g} / 100 \mathrm{~g})$, rye $(14.07 \mathrm{~g} / 100 \mathrm{~g})$, sorghum (19.59 g/100g) (Ragaee et al., 2006), wheat bran $(42.49 \mathrm{~g} / 100 \mathrm{~g})$, rice bran $(35.67$ $\mathrm{g} / 100 \mathrm{~g})$, oat bran $(11.5 \mathrm{~g} / 100 \mathrm{~g})$, barley bran (34. 2 $\mathrm{g} / 100 \mathrm{~g}$ ) (Sudha et al., 2007).

The consumption of $10 \mathrm{~g}$ per day of these flours would represent around $27 \%$ of the recommended daily requirement for dietary fibre $\left(25 \mathrm{~g} \mathrm{day}^{-1}\right)$, as recommended by FAO/WHO (1973).

Their elevated fibre content indicated necessity for its nutritional characterization, due to its possible importance in developing physiological roles in intestinal disease reduction, as well as in the reduction of cholesterol and serum triglycerides levels (Anderson, 1993; 1994, Terry, 2001; Ferguson and Harris, 2003; Peters et al., 2003; Bingham et al., 2003).

The total ash values of LF, SLF, LSF and SLSF were higher than those reported for wheat flour
(0.7 g/100g) (Giami et al., 2005), oat bran (4.00 $\mathrm{g} / 100 \mathrm{~g})$, millet $(1.82 \mathrm{~g} / 100 \mathrm{~g})$, rye $(1.96 \mathrm{~g} / 100 \mathrm{~g})$, sorghum $(1.87 \mathrm{~g} / 100 \mathrm{~g})$ (Ragaee et al., 2006) and wheat bran $(4.21 \mathrm{~g} / 100 \mathrm{~g})$ (Bilgiçli et al., 2007).

Lipid contents of king palm flour were lower when compared with cereals such as wheat (2.6 to 3.8 $\mathrm{g} / 100 \mathrm{~g}$ ), corn (3.9 to $5.8 \mathrm{~g} / 100 \mathrm{~g}$ ), barley (3.3 to 4.6 $\mathrm{g} / 100 \mathrm{~g})$ and rye $(2.7$ to $3.5 \mathrm{~g} / 100 \mathrm{~g})$, according to values reported by Morrison (1998).

The protein contents found in LF and SLF were 9.24 and $9.75 \mathrm{~g} / 100 \mathrm{~g}$ respectively, which were compatible with those found in cereals, around 6 to $15 \mathrm{~g} / 100 \mathrm{~g}$ on average (Cozzolino, 2005). Generally, proteins found in vegetables are deficient in specific essential amino acids. However, vegetables expressively contribute to protein consumption, especially in the poor countries, because they represent protein sources of low cost, (Lajolo and Tirapegui, 1998).

This characteristic of king palm flour, in addition to others, shows differentiated properties that suggest its potential as a nutrient.

\section{Anti-nutritional factors}

Several studies have been performed on antinutritional compounds (e.g. phytate and tannin) in vegetables because of their adverse effects (Farinu and Ingrão, 1991; Câmara and Madruga, 2001). The values obtained for the anti-nutritional factors - phytate and tannin - of the flours analysed can be found in Table 3.

Table 3 - Anti-nutritional factors content in leaf flour (LF), sifted leaf flour (SLF), leaf sheath flour (LSF) and sifted leaf sheath flour (SLSF) of king palm (Archontophoenix alexandrae) residues.

\begin{tabular}{ccc}
\hline \multirow{2}{*}{ Flours } & \multicolumn{2}{c}{ Mean \pm standard deviation } \\
\cline { 2 - 3 } & Phytate $(\mathbf{m g} / \mathbf{1 0 0 g})$ & Tannins $(\mathbf{m g} / \mathbf{1 0 0 g})^{*}$ \\
\hline LF & $123.2 \pm 2.5^{\mathrm{a}}$ & $750.2 \pm 9.7^{\mathrm{a}}$ \\
SLF & $133.4 \pm 3.5^{\mathrm{b}}$ & $762.2 \pm 8.09^{\mathrm{b}}$ \\
LSF & $692.1 \pm 4.2^{\mathrm{c}}$ & $251.5 \pm 3.37^{\mathrm{c}}$ \\
SLSF & $762.5 \pm 3.2^{\mathrm{d}}$ & $281.8 \pm 7.41^{\mathrm{d}}$ \\
\hline
\end{tabular}

Average values in the same column followed by different superscript letters are significantly different $(\mathrm{P} \leq 0.05)$.

Results are mean \pm standard deviation of three determinations.

* Expressed in catechin equivalents/mg.

Phytate levels in king palm flour are not nutritionally significant, as they could be considered low when compared with soy and its derivates, where concentrations of phytic acid from 1000 to $1500 \mathrm{mg} / 100 \mathrm{~g}$ are found (Reddy et al., 1989). According to Davis (1981), diminished bioavailability of bi and trivalent minerals only occur after a $1000 \mathrm{mg} / 100 \mathrm{~g}$ concentration of phytate. On the other hand, the most utilized sources of cereal fibre which are considered to be rich in phytate, such as barley $(1000 \mathrm{mg} / 100 \mathrm{~g})$ and rice cereal $(980 \mathrm{mg} / 100 \mathrm{~g})$, or rice grains $(4900-$ $6900 \mathrm{~g} / 100 \mathrm{~g}$ ) (Reddy et al., 1989), show significantly higher values than those found in the flours studied in this work. Ingestion of high levels of phytate has been associated with adverse anti- 
nutritional effects in humans, since these compounds are known to reduce bioavailability of proteins and minerals and inhibit the action of amylolytic and proteolytic enzymes (Serraino et al., 1985; Farinu and Ingrão, 1991; Chung et al., 1998; Câmara and Madruga, 2001). However, these's also a positive role for phytate in the human body, such as risk reduction of colon cancer, (Shamsuddin, 1992; Jenab and Thompson, 2002), and antioxidant action (Empson et al., 1991). When under favourable $\mathrm{pH}$ conditions, tannins form complexes with proteins, carbohydrates, and other polymers in foods, as well as with certain metallic ions such as iron. The greater tendency of tannins to form complexes with proteins rather than with carbohydrates and other polymers could explain the low digestibility of proteins originating from legumes (Empson et al., 1991). Tannin contents in legumes vary between 0 and $2000 \mathrm{mg} / 100 \mathrm{~g}$, which are values similar to those found in king palm flour. Generally speaking, the human diet consists of several foods that contain considerable quantities of tannin. Some examples of such foods are: dry beans, peas, cereals, green leaves and vegetables, coffee, tea and certain kinds of wines (Reddy et al., 1989). Therefore, the tannin levels obtained for the flours studied in this work suggest the need to further study their potential use in human diet.

\begin{abstract}
Minerals
Mineral elements contents found in the samples were calculated from specific calibration curves for each element with a total of at least 5 points and showed a linear regression coefficient higher than 0.998 .

Mineral elements are important for the growth, development and preservation of body tissues, and perform specific functions in the human body. Mineral needs, such as calcium, magnesium, potassium, sodium, zinc, iron, and manganese are relatively elevated and the importance of their inclusion in diet has been discussed in nutrition reviews (Sgabieri, 1987; Velasquez-Melendez et al., 1997; Al-Awadi and Srikumar, 2000). Relation to inorganic elements was observed through the presence of eight elements: $\mathrm{Na}, \mathrm{K}, \mathrm{Ca}, \mathrm{Mg}, \mathrm{Fe}, \mathrm{Al}$, $\mathrm{P}, \mathrm{Mn}$, and $\mathrm{Zn}$, which have been considered essential to the metabolism of living organisms (De Angels, 1997), (Table 4).
\end{abstract}

Table 4 - Mineral contents (mg/100g) in the leaf flour (LF), sifted leaf flour (SLF), leaf sheath flour (LSF) and sifted leaf sheath flour (SLSF) of king palm (Archontophoenix alexandrae) residues.

\begin{tabular}{cccccc}
\hline Elements & $\mathbf{L F}$ & SLF & LSF & SLSF & $\begin{array}{c}\text { Detection Limit } \\
(\mathbf{m g} / \mathbf{m l})\end{array}$ \\
\hline $\mathrm{Ca}$ & $989 \pm 2.5^{\mathrm{a}}$ & $1052 \pm 2.6^{\mathrm{b}}$ & $892 \pm 2.2^{\mathrm{c}}$ & $950 \pm 2.0^{\mathrm{d}}$ & 0.01 \\
$\mathrm{Mg}$ & $850 \pm 7^{\mathrm{a}}$ & $859 \pm 9^{\mathrm{a}}$ & $919 \pm 6^{\mathrm{b}}$ & $959 \pm 6.5^{\mathrm{c}}$ & 0.001 \\
$\mathrm{Fe}$ & $6.13 \pm 0.09^{\mathrm{a}}$ & $6.89 \pm 0.02^{\mathrm{b}}$ & $6.94 \pm 0.07^{\mathrm{c}}$ & $7.58 \pm 0.08^{\mathrm{d}}$ & 0.05 \\
$\mathrm{Zn}$ & $1.12 \pm 0.03^{\mathrm{a}}$ & $1.14 \pm 0.03^{\mathrm{a}}$ & $3.11 \pm 0.15^{\mathrm{b}}$ & $3.38 \pm 0.04^{\mathrm{c}}$ & 0.001 \\
$\mathrm{Mn}$ & $1.16 \pm 0.04^{\mathrm{a}}$ & $1.39 \pm 0.04^{\mathrm{b}}$ & $5.19 \pm 0.04^{\mathrm{c}}$ & $5.41 \pm 0.06^{\mathrm{d}}$ & 0.01 \\
$\mathrm{Na}$ & $3.69 \pm 0.02^{\mathrm{a}}$ & $4.14 \pm 0.01^{\mathrm{b}}$ & $3.87 \pm 0.01^{\mathrm{c}}$ & $5.23 \pm 0.01^{\mathrm{d}}$ & 0.01 \\
$\mathrm{P}$ & $44.1 \pm 0.09^{\mathrm{a}}$ & $46.9 \pm 0.02^{\mathrm{b}}$ & $31.5 \pm 0.05^{\mathrm{c}}$ & $34.1 \pm 0.03^{\mathrm{d}}$ & 0.01 \\
$\mathrm{~K}$ & $647 \pm 1.8^{\mathrm{a}}$ & $709 \pm 2.2^{\mathrm{b}}$ & $695 \pm 0.6^{\mathrm{c}}$ & $755 \pm 0.9^{\mathrm{d}}$ & 0.01 \\
\hline
\end{tabular}

Average values in the same row followed by different superscript letters are significantly different $(\mathrm{P} \leq 0.05)$.

Results are mean \pm standard deviation of three determinations.

The minerals found in highest quantity in these flours were calcium and magnesium, essential for human nutrition have an important role in the formation of bones, teeth, and tissue in the human body (Harper et al., 1982; Franco, 1999).

The values for zinc and magnesium found, varied from 1.0 to $3.5 \mathrm{mg} / 100 \mathrm{~g}$ and 1.0 to $5.5 \mathrm{mg} / 100 \mathrm{~g}$ respectively; serve as essential activators in a series of metabolic reactions catalyzed by enzymes, and are, therefore, very important elements for reproduction and growth (Hazell, 1985, Cozzolino, 2005).

The iron content ranged from 6 to $8 \mathrm{mg} / 100 \mathrm{~g}$. Iron is an important micronutrient for human nutrition and, due to the high indexes of anaemia in Brazil, has been largely used in food fortification programs (Hazell, 1985, Torres et al., 1996).

The values found for sodium and potassium, varied from 3 to $5 \mathrm{mg} / 100 \mathrm{~g}$ and 640 to 750 $\mathrm{mg} / 100 \mathrm{~g}$, respectively. These minerals regularize 
muscular system function and heartbeat when found in association (Franco, 1999).

When compared with the daily mineral requirement values recommended by the RDA (1989) and the WHO (1996) (Table 5), king palm flour showed high mineral content. Consumption of $100 \mathrm{~g}$ of this flour could provide, from a minimum $12 \%$ of $\mathrm{Zn}$, to $100 \%$ of the RDA of $\mathrm{Ca}$, $\mathrm{Mg}$ and $\mathrm{K}$. Other elements were between 12 and $100 \%$. However, the bioavailability of most minerals cold be affected by high dietary fibre concentrations and other anti-nutritional compounds found in this product (Hazell, 1985; Cozzolino, 2005).

Table 5 - Daily requirements of some minerals recommended by the WHO and RDA.

\begin{tabular}{cll}
\hline Elements & WHO $(\mathbf{m g})^{*}$ & RDA $(\mathbf{m g})^{*}$ \\
\hline $\mathrm{Ca}$ & $400-500$ & $800-1200$ \\
$\mathrm{Fe}$ & $10^{(\mathrm{M})}, 20^{(\mathrm{W})}$ & $10^{(\mathrm{M})}, 15^{(\mathrm{W})}$ \\
$\mathrm{K}$ & - & 2000 \\
$\mathrm{Mg}$ & 300 & $350^{(\mathrm{M})}, 280^{(\mathrm{W})}$ \\
$\mathrm{Mn}$ & $2-3$ & $2-5$ \\
$\mathrm{Na}$ & - & 500 \\
$\mathrm{Zn}$ & $10-15$ & $15^{(\mathrm{M})}, 12^{(\mathrm{W})}$ \\
\hline
\end{tabular}

*Recommended for young adults (19-24 years) (RDA, 1989, WHO, 1996)

(M) recommended for men; (W) recommended for women.

Results are mean \pm standard deviation of three determinations.

In spite of satisfactory results, the utilization of king palm flour requires studies on the bioavailability of minerals and toxicity in order to guarantee safety before its utilization in formulations for human nutrition could be suggested. The king palm residues studied in this work were a part of the raw material that required adequate manipulation to be used in flour production, converting residues into value in the food industry.

\section{ACKNOWLEDGMENTS}

The authors would like to thank the Conselho Nacional de Desenvolvimento Científico e Tecnológico - CNPq, Brazil, for their financial support of this research.

\section{RESUMO}

Resíduos do processamento de palmeira-real (Archontophoenix alexandrae) foram utilizados para produção de farinha e caracterizados quimicamente. O conteúdo de proteína encontrado nas farinhas variam de 3,62 a 9,75, sendo maior na farinha da folha peneirada. Os teores de fibra dietética total variaram de 64.00 a $72 \mathrm{~g} / 100 \mathrm{~g}$, valores altos quando comparados com farinhas tradicionalmente utilizadas na alimentação humana. A análise de fatores antinutricionais indicou teores de fitato abaixo dos níveis que afetam a biodisponibilidade de minerais na dieta. Os teores de tanino foram significativos, compatíveis aos encontrados nas leguminosas entre 0 e $2000 \mathrm{mg} / 100 \mathrm{~g}$. As farinhas de palmeirareal apresentaram elevados teores de minerais, podendo ser indicadas como suplementos em alimentos, porém, deve-se considerar que a biodisponibilidade destes minerais pode ser afetada pela alta concentração de fibras dietéticas totais e de outros componentes antinutricionais contidos na amostra.

\section{REFERENCES}

Al-Awadi, F. M. and Srikumar, T. S. (2000).Traceelement status in milk and plasma of Kuwaiti and non-Kuwaiti lactating mothers. Nutrition, 6, 10691073.

Almeida, M. B.; Lopes, M. F. G.; Nogueira, C. M. D.; Magalhães, C. E. C. and Morais, N. M. T. (2002). Determinação de nutrientes Minerais em Plantas Medicinais. Ciência Tecnologia Alimentos, 22, 94-97.

Amante, E. R.; Junior, A.B.; Kanzawa, A.; Ensslin, L. and Muraki, M. (1999). Um panorama da tecnologia limpa na indústria de alimentos. Revista da Sociedade Brasileira de Alimentos, 33, 16-21.

American Association of Cereal Chemists - AACC (1999). Approved Methods 9 ed. St. Paul, Minnesota $1345 \mathrm{p}$.

Anderson, J. W. (1993). Fibra, doença cardiovascular e diabetes. Diéta e Saúde, 2, 4-5. 
Association of Official Analytical Chemists - AOAC (1990). Official methods of analysis of the Association Analitical Chemists. 14th ed. Washington, D.C.1298p.

Association of Official Analytical Chemists - AOAC (1998). Official Methods of analysis of the Association Analitical Chemists. 15th ed. Washington, D.C.. 1298p.

Bilgiçli, N.; Ibanoglu, S. and Herken, E. N. (2007) Effect od dietary fibre addition on the selected nutritional properties of cookies. Journal of Food Engineering, 78, 86-89.

Bingham, S. A.; Day, N. E.; Luben, R.; Ferrari, P.; Slimani, N.; Norat, T.; Clavel-Chapelon, F. and Kesse, E. (2003). Dietary fibre in food and protection against cholesterol cancer in the European prospective investigation into cancer and nutritional (EPIC): an observational study. The lancet, 57, 9-14.

Bovi, M. L. A. (1998). Cultivo da palmeira real australiana visando a produção de palmito. (Cultivation of Alexandra palm aiming heart - of palm production). Campinas: Instituto Agronômico, 26p. (Boletim Técnico 172).

Bovi, M. L. A. and Spiering, S. H. (2004). Características físicas e produção de palmito de palmeira real australiana. In: Congresso Brasileiro de Olericultura, 43, 2003. Recife. Anais..., Brasília: SOB.. 4p.

Câmara, S. F. and Madruga, M. S. (2001). Yanic acid, phytic acid, total tannin and aflatoxin contents of a Brazilian (natal) multimistura preparation. Revista Nutrição, 14, 33-36.

Chaudhary, V. K. and Weber, F. E. (1990). Rye flour evaluated as dietary fibre ingredient in wheat bread. Cereal Food World, 35, 560-562.

Chung, K. T.; Wong, T. Y.; Wei, C. I.; Huang, Y. W. and LIN, Y. (1998). Tannins and Human health: a review. Critical Reviews in Food Nutritional, Amherst, 38, 421-464.

Comissão Nacional de Normas e Padrões para Alimentos - CNNPA (1978). Resolução 12/78 Alimentos e bebidas: 47 padrões de identidade e qualidade. In: Associação Brasileira das indústrias de Alimentação. Compêndio de resoluções da CNNPA. São Paulo; ABIA, 1978. 281p.

Cozzolino, S. M. F. (2005). Biodisponibilidade de nutrientes. Barueri, SP, Brasil, Vol. 1., 878p.

Davis, K. R. (1981). Proximate composition, phytic acid, and total phosphorus of selected breakfast cereals. Cereal Chemistry, 58, 347-350.

De Angels, R. C. (1977). Fisiologia da nutrição: fundamentos para nutrição e para desnutrição. EDASRT, 2, 55-76.

Empson, K. L.; Labuza, T. P. and Graf, E. (1991). Phytic acid as a food antioxidant. Journal Food Science, 56, 560-563.
Farinu, G. and Ingrão, G. (1991). Gross composition, amino acid, phytic acid and trace element contents of thirteen cowpea cultivars and their nutritional significance. Journal of the Science of Food and Agriculture, 55, 401-410.

Ferguson, L. R. and Harris, P. J. (2003). The dietary fibre debate: more food for thought. The Lancet, $\mathbf{3 6 1}$ 1487-1488, 2003.

Filizette-Cozzi, T. M. C. C. and Lajolo, F. M. (1991). Fibra alimentar insolúvel, solúvel e total em alimentos brasileiros. Revista Farmácia $e$ Bioquímica, 27, 85-99.

Food and Agriculture Organisation of the United Nation - FAO/WHO (1973). Energy and Protein Requirements. Food and Agriculture Organisation Nutrition meeting report Series 52, Rome: World Health Organisation Technical Report Series, 522.

Franco, F. (1999).Tabela de Composição de Alimentos. $9^{a}$ ed., Atheneu, São Paulo.

Giami, S.; Achinewhu, S. C. and Ibaakee, C. (2005). The quality and sensory atributes of cookies supplemented with fluted pumpkin (Telfairia occidentalis Hook) seed flour. International Journal of Food Science and Technology, 40, 613-620.

Grupta, S.; Lakshmi, A. J.; Manjunath, M. N.and Prakash, J. (2004). Analysis of nutrient and antinutrient content of underutilized green leafy vegetables. Food Science and Technology, 38, 339345.

Harper, H. A.; Rodwelf, V. W. and Mayes, R. A. (1982). Manual de Química Fisiológica. 5ed., Atheneu, São Paulo Brasil. 350p.

Hazell, T. (1985). Minerals in food: Dietary sources, chemical forms, interactions, biovailability. Word Review of Nutrition an Dietetic, 46, 1-123.

Jenab, M. and Thompson, L. U. Role of phytic acid in cancer and other diseases. In: Reddy, N.R., Sathe, S.K. (Eds.), Food Phytates. CRC Press, Boca Raton, FL, p. 225-248, 2002.

Kawashima, L. M. and Soares, L. M. V. (2003). Mineral profile of raw and cooked leafy vegetables consumed in Southern Brazil. Journal of Food Composition and Analysis, 16, 605-611.

Lajolo, F. M. and Tirapegui, J. (1998). Proteínas e aminoácidos. In: Oliveira, J. E. D.; Marchini, J. S. (eds.). Ciências nutricionais. São Paulo, Brasil, 3960.

Matias, M. de F. O; Oliveira, E. L. de; Gertrudes, E and Magalhães, M. M. dos A. (2005). Use of fibres obtained from the cashew (Anacardium ocidentale, L) and guava (Psidium guayava) fruits for enrichment of food products. Braz. Arch. Biol. Technol. 48, 143150.

Morrison, W. R. (1998). Cereal lipds. In: Pomeranz, Y. Advances in cereal Science and Technology, Saint Paul 2, 221-288. 
Oliveira, L. F.; Nascimento, M. R. F.; Borges, S. V.; Ribeiro, P. C. N. and Ruback, V. R. (2002). Aproveitamento alternativo da casca do maracujáamarelo (Passiflora edulis) Para produção de doce em calda. Ciência e Tecnologia de Alimentos, 22, 259-262.

Paduá, M de; Fontoura, P. S. G. and Mathias, A. L.. (2004). Chemical composition of Ulvaria oxysperma (Kützing) bliding, Ulva lactuca (Linnaeus) and Ulva fascita (Delile). Braz. arch. biol. technol., 47, 49-55.

Peters, U.; Sinha R.; Chatterjee N.; Subar A. F.; Ziegler, R. G. and Kulldorff, M. (2003). Dietary fibre and colorectal adenoma in a colorectal cancer early detection programme. The Lancert, 361, 1491-1495.

Porres, J. M.; Aranda, P.; Jurado-López, M. and Urbano, G. (2005). Nutritional potential of raw free galactosides lupin (Lupinus albus Var. Multolupa) seed flours. Effect of phytase treatment on nitrogen and mineral dialyzibility. Journal Agricultural Food Chemistry, 53, 3088-3094.

Price, M. L.; Scoyoc, S. V. and Butler, L. G. (1978). A critical evalution of the vanillin reaction as assay for tannin in sorghum grain. Journal Agricultural Food Chemistry, 26, 1214-1218.

Ragaee, S.; Abdel-Aal, E. 1.; Sayed, .M. and Noaman, M. (2006) Antioxidant activity nutrient composition of selected cereals for food use. Food Chemistry, 98, 32-38.

Ramos, M. G. and Heck, T. C. (2003). Cultivo da palmeira-real-da-austrália para a produção de palmito. Florianópolis: Epagri, Boletim Didático. 2, $32 \mathrm{p}$.

Recommended Dietary Allowances - RDA (1989), Recommended Dietary Allowances $10^{\text {th }}$, National Research Council, National Academy Press, Washington, DC, 284p.

Reddy, N. R.; Pierson, M. D.; Sathe, S. K. and Salunkhe, D. K. (1989). Phytates in Cereals and Legumes. Boca Raton, Florida. 152p.

Ribeiro, J. H. (1996). SOS Palmito. Revista Globo Rural, 3 , 24-26.

Serraino, M. R.; Thompson, L. U.; Savoie, L. and Parent, G. (1985). Effect of phytic acid. On the invitro rate of digestibility of rapeseed protein and amino acid. Journal Food Science, 50, 1689-1692.

Sgabieri, W. C. (1987). Alimentação e nutrição: Fator de saúde e desenvolvimento. Unicamp/Almed, Campinas/São Paulo.

Shamsuddin, A. M. Phytate and colon-cancer risk. American Journal Clinical nutrition, 55, n. 2, p. 478, 1992.

Silva, M. R.; Silva, M. S.; Martins, K. A. and Borges, S. (2001). Utilização tecnológica dos frutos de jatobádo-cerrado e de jatobá-da-mata na elaboração de biscoitos fontes de fibras alimentares e isentos de açúcares. Ciência e Tecnologia de Alimentos, 21, 176-182.
Simas, K. de N.; Vieira, L. do N.; Podestá, R.; Muller, C. M. O.; Vieira, M. A.; Beber, R. C.; Reis, M. S.; Barreto, P. L. M.; Amante, E. R. and Amboni, R. D. M. C. (2009). Effect of king palm (Archontophoenix alexandrae) flour incorporation on physicochemical and texture characteristics of gluten-free cookie. International Journal of Food Science and Technology, 44, 531-538.

Sudha, M.L.; Vetrimani, R. and Leelavathi. (2007). Influence of fibre from different cereals on the rheological characteristics of wheat flour dough and on biscuit quality. Food Chemistry, 100, 1365-1370

Terry, F. C. (2001). Fruit, vegetables dietary fibre, and risk of cholesterol and cancer. Journal of National Cancer Institute. 93, 525-533.

Thompson, D. B. and Erdman, J. W. (1982). Phytic acid determination in soybeans. Journal of Food Science. 47, 513-517.

Torres, M. A. A.; Lobo, N. F.; Sato, K. and Queiroz, S. S. (1996). Fortificação do leite fluido na prevenção e tratamento da anemia carencial ferropriva em crianças menores de 4 anos. Revista de Saúde Pública, 30, 350- 357.

United States Department of Agriculture - USDA (2002). Nutrient Database for Standard Reference. Release 15, Nutrient. Data Laboratory, Beltsvile Research Center, US Departament of Agriculture, 2002.

Velasquez-Melendez, G.; Salas, M. I. and Cervato, A. M. (1997). Consumo alimentar de vitaminas e minerais em adultos residentes em área metropolitana de São Paulo, Brasil. Revista Saúde Pública, 31,157162.

Vieira, M. A.; Tramonte, K. C.; Podesta, R.; Avancini, S. R. P.; Amboni, R. D. M. C. and Amante, E. R. (2008). Physicochemical and sensory characteristics of cookies containing residue from king palm (Archontophoenix alexandrae) processing. International Journal and Food Science Technology, 43, 1534-1540.

Watt, B. and Merrill, A. L. (1999). Composition of foods: raw, processed, prepared. Maryland: US. Department of Agricultural, Agricultural Research Service, USDA Nutrient Data Laboatory. USDA Nutrient Database for Standart Reference, Release, 13. Disponível em: http://www.nal.usda.gov/fnic/foodcomp Acesso em 25 de janeiro de 2006.

World Health Organization - WHO (1996). Trace elements in human nutrition and health.Geneva.

Received: June 08, 2006; Revised: March 29, 2007; Accepted: December 23, 2008 